\title{
LEVEL II SCOUR ANALYSIS FOR BRIDGE 45 (CHELTH00440045) on TOWN HIGHWAY 44, crossing the FIRST BRANCH WHITE RIVER, CHELSEA, VERMONT
}

U.S. Geological Survey Open-File Report 96-241

Prepared in cooperation with

VERMONT AGENCY OF TRANSPORTATION and

FEDERAL HIGHWAY ADMINISTRATION 


\section{LEVEL II SCOUR ANALYSIS FOR BRIDGE 45 (CHELTH00440045) on TOWN HIGHWAY 44, crossing the FIRST BRANCH WHITE RIVER, CHELSEA, VERMONT}

By JOSEPH D. AYOTTE and ROBERT E. HAMMOND

U.S. Geological Survey Open-File Report 96-241

Prepared in cooperation with

VERMONT AGENCY OF TRANSPORTATION and

FEDERAL HIGHWAY ADMINISTRATION 


\title{
U.S. DEPARTMENT OF THE INTERIOR BRUCE BABBITT, Secretary
}

\author{
U.S. GEOLOGICAL SURVEY \\ Gordon P. Eaton, Director
}

For additional information write to:

District Chief

U.S. Geological Survey 361 Commerce Way

Pembroke, NH 03275
Copies of this report may be purchased from:

U.S. Geological Survey Earth Science Information Center Open-File Reports Section Box 25286, MS 517 Federal Center

Denver, CO 80225 


\section{CONTENTS}

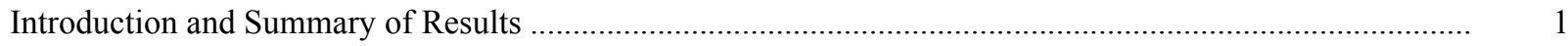

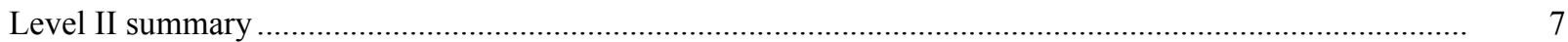

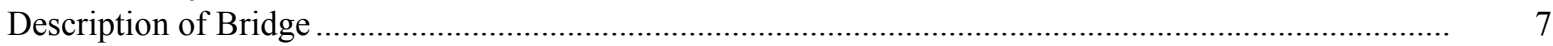

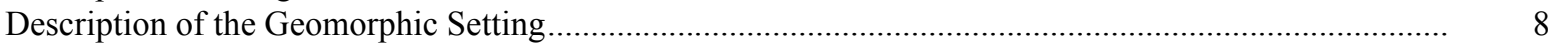

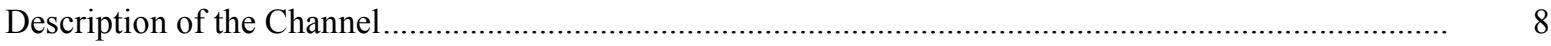

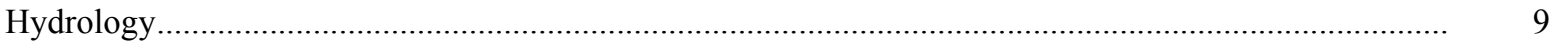

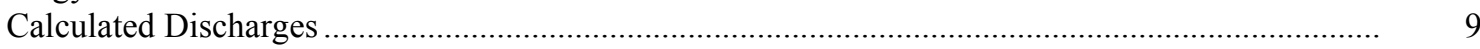

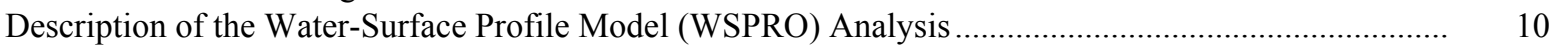

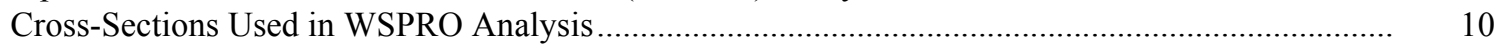

Data and Assumptions Used in WSPRO Model ...................................................................... 11

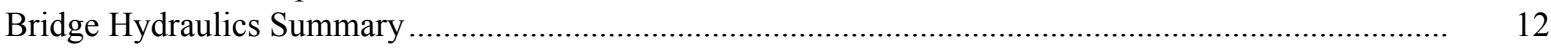

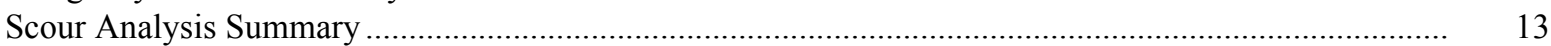

Special Conditions or Assumptions Made in Scour Analysis ...................................................... 13

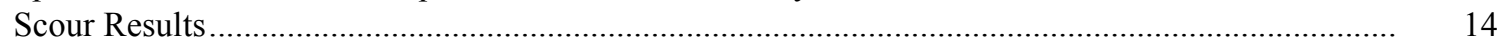

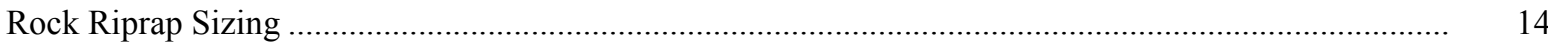

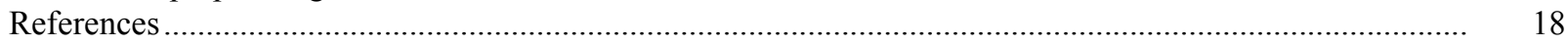

Appendixes:

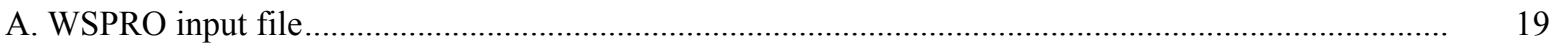

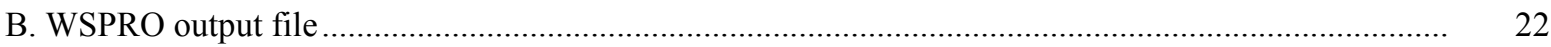

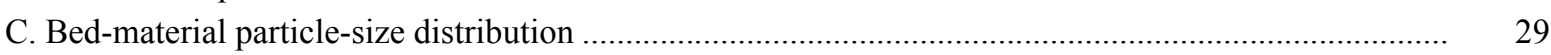

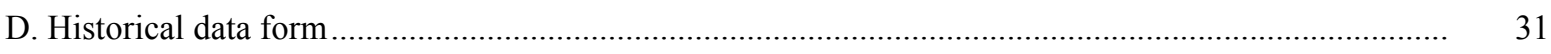

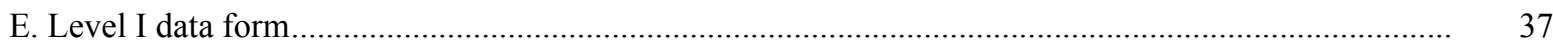

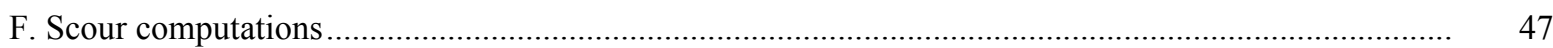

\section{FIGURES}

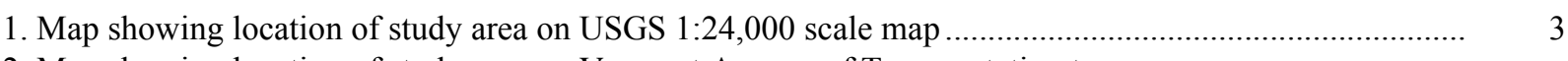

2. Map showing location of study area on Vermont Agency of Transportation town

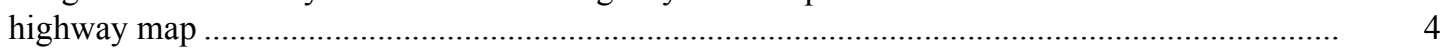

3. Structure CHELTH00440045 viewed from upstream (November 17, 1994) ......................................... 5

4. Downstream channel viewed from structure CHELTH00440045 (November 17, 1994)........................ 5

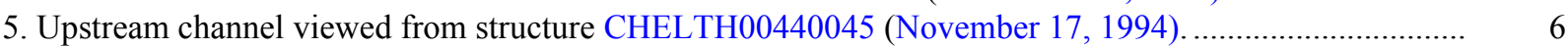

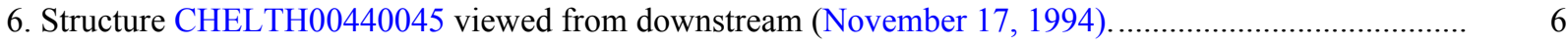

7. Water-surface profiles for the 100- and 500-year discharges at structure

CHELTH00440045 on Town Highway 44, crossing First Branch White River,

Chelsea, Vermont.

8. Scour elevations for the 100- and 500-year discharges at structure

CHELTH00440045 on Town Highway 44, crossing First Branch White River,

Chelsea, Vermont.

\section{TABLES}

1. Remaining footing/pile depth at abutments for the 100-year discharge at structure CHELTH00440045 on Town Highway 44, crossing First Branch White River,

Chelsea, Vermont.

2. Remaining footing/pile depth at abutments for the 500-year discharge at structure

CHELTH00440045 on Town Highway 44, crossing First Branch White River,

Chelsea, Vermont.

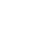

5

(

6




\begin{tabular}{|c|c|c|}
\hline Multiply & By & To obtain \\
\hline \multicolumn{3}{|c|}{ Length } \\
\hline inch (in.) & 25.4 & millimeter (mm) \\
\hline foot $(\mathrm{ft})$ & 0.3048 & meter $(\mathrm{m})$ \\
\hline mile (mi) & 1.609 & kilometer (km) \\
\hline \multicolumn{3}{|c|}{ Slope } \\
\hline foot per mile ( $\mathrm{ft} / \mathrm{mi})$ & 0.1894 & meter per kilometer $(\mathrm{m} / \mathrm{km})$ \\
\hline \multicolumn{3}{|c|}{ Area } \\
\hline square mile $\left(\mathrm{mi}^{2}\right)$ & 2.590 & square kilometer $\left(\mathrm{km}^{2}\right)$ \\
\hline \multicolumn{3}{|c|}{ Volume } \\
\hline cubic foot $\left(\mathrm{ft}^{3}\right)$ & $\begin{array}{l}0.02832 \\
\text { Velocity and Flow }\end{array}$ & cubic meter $\left(\mathrm{m}^{3}\right)$ \\
\hline foot per second (ft/s) & 0.3048 & meter per second $(\mathrm{m} / \mathrm{s})$ \\
\hline cubic foot per second $\left(\mathrm{ft}^{3} / \mathrm{s}\right)$ & 0.02832 & cubic meter per second $\left(\mathrm{m}^{3} / \mathrm{s}\right)$ \\
\hline $\begin{array}{l}\text { cubic foot per second per } \\
\text { square mile } \\
{\left[\left(\mathrm{ft}^{3} / \mathrm{s}\right) / \mathrm{mi}^{2}\right]}\end{array}$ & 0.01093 & $\begin{array}{l}\text { cubic meter per } \\
\text { second per square } \\
\text { kilometer }\left[\left(\mathrm{m}^{3} / \mathrm{s}\right) / \mathrm{km}^{2}\right]\end{array}$ \\
\hline
\end{tabular}

OTHER ABBREVIATIONS

$\begin{array}{lrlr}\mathrm{BF} & \text { bank full } & \text { LWW } & \text { left wingwall } \\ \mathrm{cfs} & \text { cubic feet per second } & \text { MC } & \text { main channel } \\ \mathrm{D}_{50} & \text { median diameter of bed material } & \text { RAB } & \text { right abutment } \\ \mathrm{DS} & \text { downstream } & \text { RABUT } & \text { face of right abutment } \\ \mathrm{elev} & \text { elevation } & \text { RB } & \text { right bank } \\ \mathrm{f} / \mathrm{p} & \text { flood plain } & \text { ROB } & \text { right overbank } \\ \mathrm{ft} & \text { square feet } & \text { RWW } & \text { right wingwall } \\ \mathrm{ft} / \mathrm{ft} & \text { feet per foot } & \text { TH } & \text { town highway } \\ \mathrm{JCT} & \text { junction } & \text { UB } & \text { under bridge } \\ \mathrm{LAB} & \text { left abutment } & \text { US } & \text { upstream } \\ \mathrm{LABUT} & \text { face of left abutment } & \text { USGS } & \text { United States Geological Survey } \\ \text { LB } & \text { left bank } & \text { VTAOT Vermont Agency of Transportation } \\ \text { LOB } & \text { left overbank } & \text { WSPRO } & \text { water-surface profile model }\end{array}$

In this report, the words "right" and "left" refer to directions that would be reported by an observer facing downstream. Sea level: In this report, "sea level" refers to the National Geodetic Vertical Datum of 1929-- a geodetic datum derived from a general adjustment of the first-order level nets of the United States and Canada, formerly called Sea Level Datum of 1929.

In the appendices, the above abbreviations may be combined. For example, USLB would represent upstream left bank. 


\title{
LEVEL II SCOUR ANALYSIS FOR BRIDGE 45 (CHELTH00440045) ON TOWN HIGHWAY 44, CROSSING the FIRST BRANCH WHITE RIVER, CHELSEA, VERMONT
}

\author{
By Joseph D. Ayotte and Robert E. Hammond
}

\section{INTRODUCTION AND SUMMARY OF RESULTS}

This report provides the results of a detailed Level II analysis of scour potential at structure CHELTH00440045 on town highway 44 crossing the First Branch White River, Chelsea, Vermont (figures 1-8). A Level II study is a basic engineering analysis of the site, including a quantitative analysis of stream stability and scour (U.S. Department of Transportation, 1993). A Level I study is included in Appendix E of this report. A Level I study provides a qualitative geomorphic characterization of the study site. Information on the bridge available from VTAOT files was compiled prior to conducting Level I and Level II analyses and can be found in Appendix D.

The site is in the Green Mountain physiographic province of central Vermont in the town of Chelsea. The 32.5- $\mathrm{mi}^{2}$ drainage area is in a predominantly rural and forested basin. In the vicinity of the study site, the banks have low to moderate woody vegetation coverage except for the upstream right bank, which is grass covered. The immediate vicinity of the site is suburban and the overbank areas are occupied by houses, driveways, and lawn areas. The upstream right bank area is a dirt parking lot for a small auto repair garage.

In the study area, the First Branch White River has an incised, sinuous channel with a slope of approximately $0.003 \mathrm{ft} / \mathrm{ft}$, an average channel top width of $41 \mathrm{ft}$ and an average channel depth of $4 \mathrm{ft}$. The predominant channel bed material is gravel $\left(\mathrm{D}_{50}\right.$ is $43.1 \mathrm{~mm}$ or $\left.0.141 \mathrm{ft}\right)$. The geomorphic assessment at the time of the Level I and Level II site visit on November 17,1994 , indicated that the reach was stable.

The town highway 44 crossing of the First Branch White River is a 31-ft-long, two-lane bridge consisting of one 27-foot clear-span concrete-encased steel beam deck superstructure (Vermont Agency of Transportation, written commun., August 25, 1994). The bridge is supported by vertical, concrete abutments with wingwalls. The channel is skewed approximately 10 degrees to the opening while the opening-skew-to-roadway is 5 degrees. 
Both abutment footings were reported as exposed and the left abutment was reported to be undermined by $0.5 \mathrm{ft}$ at the time of the Level I assessment. The only scour protection measure at the site was type-1 stone fill (less than 12 inches diameter) along the left abutment which was reported as failed. Additional details describing conditions at the site are included in the Level II Summary and Appendices D and E.

Scour depths and rock rip-rap sizes were computed using the general guidelines described in Hydraulic Engineering Circular 18 (Richardson and others, 1993). Total scour at a highway crossing is comprised of three components: 1) long-term streambed degradation; 2) contraction scour (due to accelerated flow caused by a reduction in flow area at a bridge) and; 3) local scour (caused by accelerated flow around piers and abutments). Total scour is the sum of the three components. Equations are available to compute depths for contraction and local scour and a summary of the results of these computations follows.

Contraction scour for all modelled flows ranged from 0.4 to $5.1 \mathrm{ft}$. with the worst-case occurring at the 500-year discharge. Abutment scour ranged from 9.9 to $20.3 \mathrm{ft}$. The worstcase abutment scour also occurred at the 500-year discharge. Additional information on scour depths and depths to armoring are included in the section titled "Scour Results". Scoured-streambed elevations, based on the calculated scour depths, are presented in tables 1 and 2. A cross-section of the scour computed at the bridge is presented in figure 8. Scour depths were calculated assuming an infinite depth of erosive material and a homogeneous particle-size distribution.

It is generally accepted that the Froehlich equation (abutment scour) gives "excessively conservative estimates of scour depths" (Richardson and others, 1993, p. 48). Many factors, including historical performance during flood events, the geomorphic assessment, scour protection measures, and the results of the hydraulic analyses, must be considered to properly assess the validity of abutment scour results. Therefore, scour depths adopted by VTAOT may differ from the computed values documented herein, based on the consideration of additional contributing factors and experienced engineering judgement. 


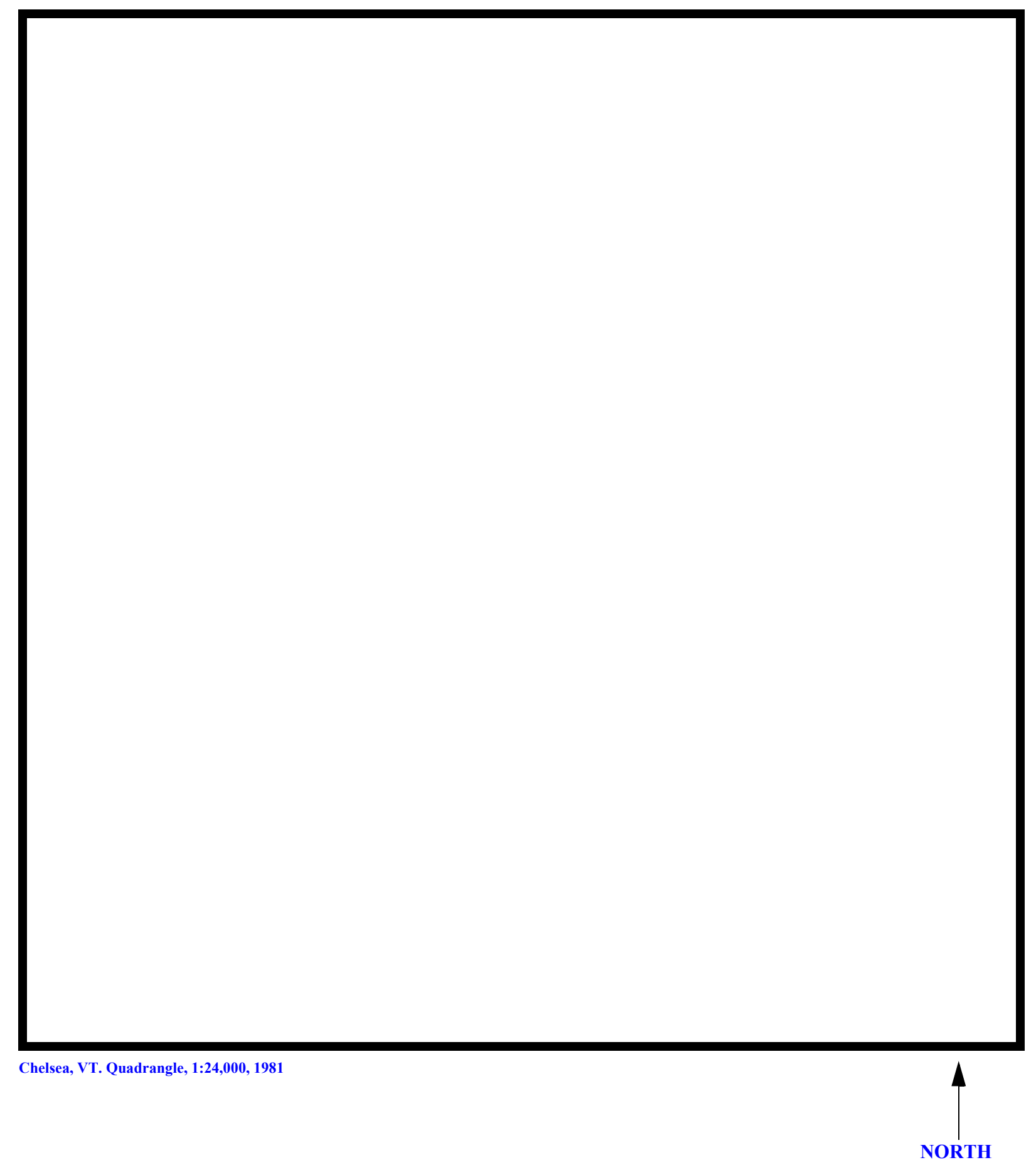

Figure 1. Location of study area on USGS 1:24,000 scale map. 
Figure 2. Location of study area on Vermont Agency of Transportation town highway map. 

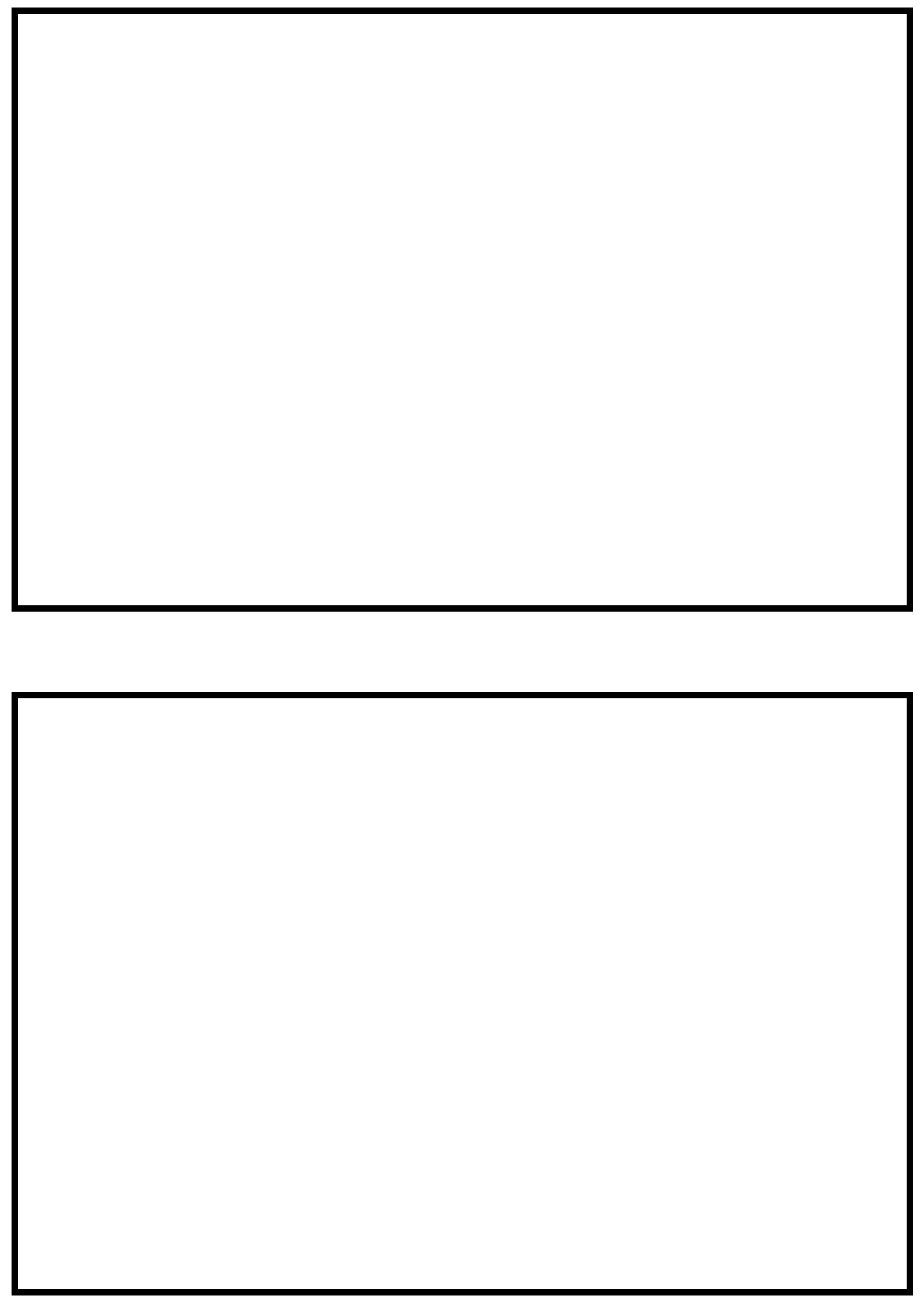

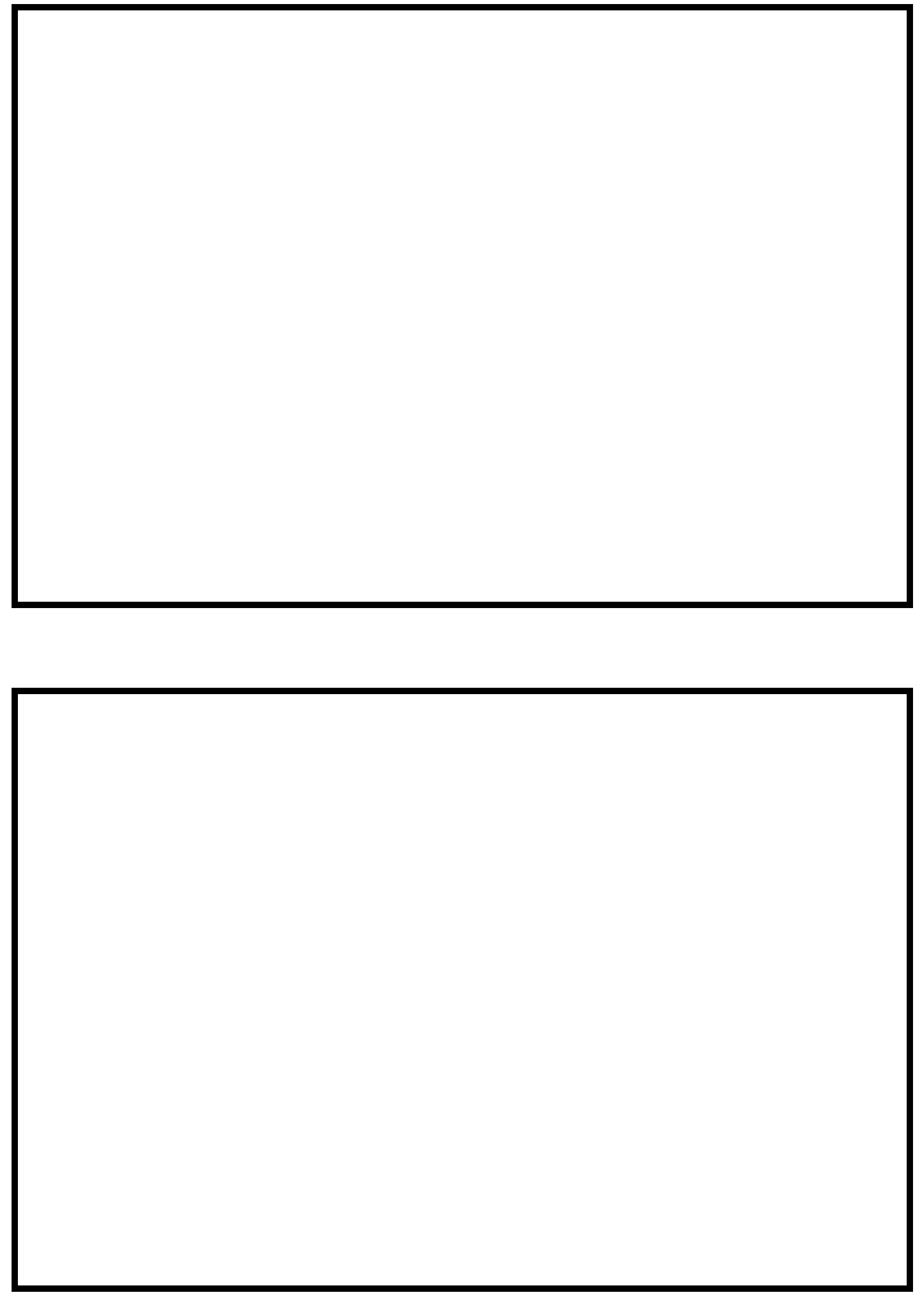


\section{LEVEL II SUMMARY}

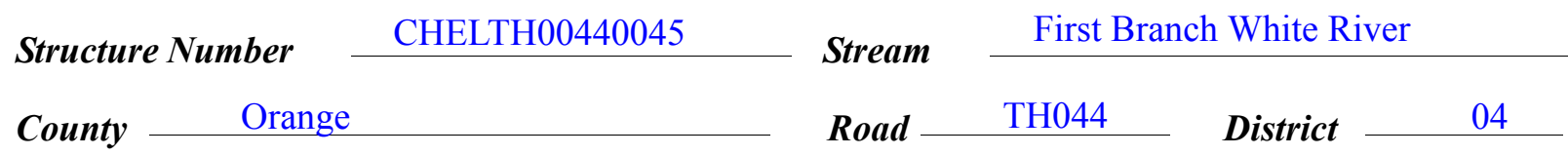

\section{Description of Bridge}

Bridge length $\stackrel{31}{n} \boldsymbol{f t} \quad$ Bridge width $\stackrel{22.4}{f t}$ Max span length $\stackrel{27}{ } \boldsymbol{f t}$ Alignment of bridge to road (on curve or straight) Vertical Abutment type

Stone fill on abutment? Yes

Embankment type Straight

Damanimtin... af ata... f fill

Dato af incnortion sloping $11 / 17 / 94$ reported along the right abutment. Type-1, along the left abutment reported as failed. No protection is Abutments and wingwalls are concrete. There is $0.5 \mathrm{ft}$ of undermining of the left abutment.

\section{$\mathrm{Y}$} 10

Is bridge skewed to flood flow according to N_ ' survey? Angle

Debris accumulation on bridge at time of Level I or Level II site visit:

\begin{tabular}{|c|c|c|c|}
\hline & $\begin{array}{c}\text { Date of insnortion } \\
11 / 17 / 94 \\
\end{array}$ & $\begin{array}{l}\text { Percent of alommol } \\
\text { blocked inortzontatly }\end{array}$ & $\begin{array}{l}\text { Percent of } 0 . \ldots e l \\
\text { blocked verticatty }\end{array}$ \\
\hline el I & $11 / 17 / 94$ & -- & -- \\
\hline & Low. & & \\
\hline
\end{tabular}

\section{Potential for debris}

There is a small farm-type bridge several hundred feet DS of the bridge which may cause Dosariho anv, foaturos noar ar at tho hridoo that mav affoct flow, (includo ahsorvation datol backwater; this structure was ignored for the analyses presented in this report (11/17/94.) 


\section{Description of the Geomorphic Setting}

General topography The channel is located within a 1,000 foot-wide, flat to slightly irregular flood plain with steep valley walls on both sides.

Geomorphic conditions at bridge site: downstream (DS), upstream (US)

Date of inspection $\quad 11 / 17 / 94$

DS left: $\quad$ Wide flood plain.

DS right: Wide flood plain

US left: $\quad$ Wide flood plain

US right: Wide flood plain

\section{Description of the Channel}

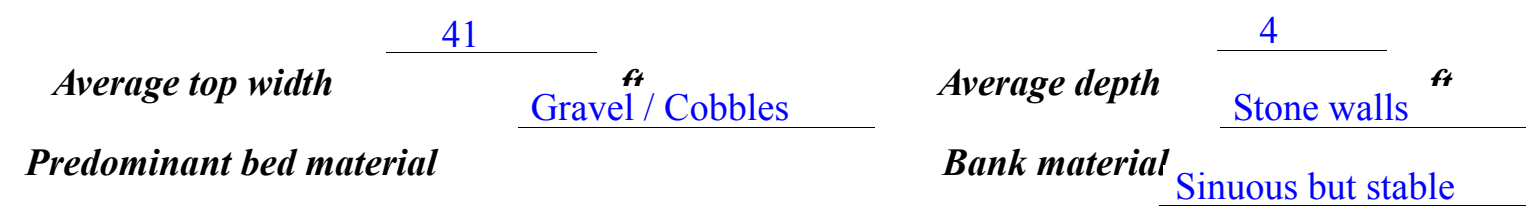

with alluvial and man-made channel boundaries and a wide floöd plain.

$11 / 17 / 94$

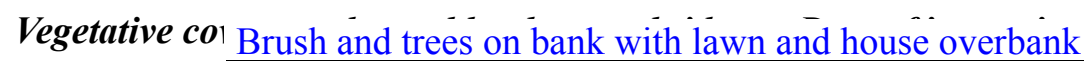

DS left: $\quad$ Few trees and brush on bank with lawn and house overbank

DS right: $\quad$ Brush and some trees; dry wall, with dirt lot and house and garage

US left: $\quad$ Trees and brush on bank, gravel driveway overbank.

US right: $\quad \underline{\mathrm{Y}}$

Do banks appear stable? -

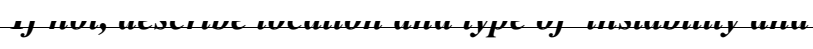

date of observatton.

None as of $11 / 17 / 94$

Describe any obstructions in channel and date of observation. 


\section{Hydrology}

Drainage area $\stackrel{32.5}{\boldsymbol{m i}^{2}}$

Percentage of drainage area in physiographic provinces: (approximate)

Physiographic province

Green Mountain
Percent of drainage area

100

Is drainage area considered rural or urban?

Rural

The drainage area is largely rural but the site is located in a suburban area of the town of Chelsea

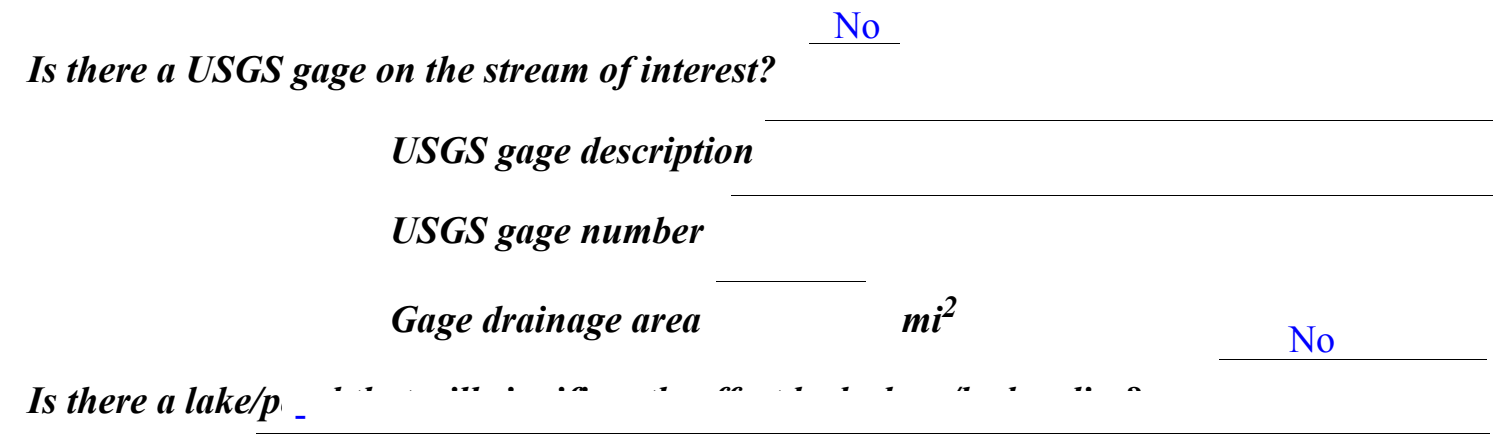

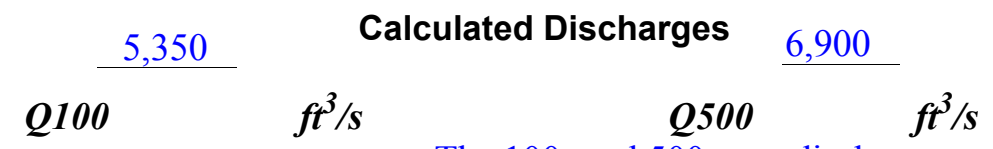

The 100- and 500-year discharges are based on

several empirical methods (Talbot, 1887; Potter, 1957a \& b; Johnson and Laraway, 1971, written commun.; Johnson and Tasker, 1974; Federal Highway Administration, 1983) and a drainage area relationship [(32.5/58.2)exp 0.7] with bridge number 46 in Chelsea. Bridge 46 on the First Branch White River in Chelsea had a drainage area 58.2 square miles and an estimated Q100 of $7,900 \mathrm{cfs}$. The discharge at bridge 46 was selected from a range of empirical methods applicable to a site in this region. 


\section{Description of the Water-Surface Profile Model (WSPRO) Analysis}

Datum for WSPRO analysis (USGS survey, sea level, VTAOT plans)

USGS survey

Datum tie between USGS survey and VTAOT plans

None

Description of reference marks used to determine USGS datum. $\quad$ RM1 is a chiseled X on

DS right guard-rail footing (elev. $501.70 \mathrm{ft}$, arbitrary datum). RM2 is a chiseled X on top of the

US end of the left abutment (elev. $500.55 \mathrm{ft}$, arbitrary datum).

\section{Cross-Sections Used in WSPRO Analysis}

\begin{tabular}{|c|c|c|c|}
\hline${ }^{1}$ Cross-section & $\begin{array}{c}\text { Section } \\
\text { Reference } \\
\text { Distance } \\
\text { (SRD) in feet }\end{array}$ & $\begin{array}{c}{ }^{2} \text { Cross-section } \\
\text { development }\end{array}$ & Comments \\
\hline EXITX & -60 & 1 & Exit section \\
\hline FULLV & 0 & 2 & $\begin{array}{l}\text { Downstream Full-valley } \\
\text { section (Templated from } \\
\text { EXITX) }\end{array}$ \\
\hline BRIDG & 0 & 1 & Bridge section \\
\hline RDWAY & 12 & 1 & Road Grade section \\
\hline APPRO & 50 & 1 & Approach section \\
\hline
\end{tabular}

${ }^{1}$ For location of cross-sections see plan-view sketch included with Level I field form, Appendix E. For more detail on how cross-sections were developed see WSPRO input file. 


\section{Data and Assumptions Used in WSPRO Model}

Hydraulic analyses of the reach were done by use of the Federal Highway Administration's WSPRO step-backwater computer program (Shearman and others, 1986, and Shearman, 1990). The analyses reported herein reflect conditions existing at the site at the time of the study. Furthermore, in the development of the model it was necessary to assume no accumulation of debris or ice at the site. Results of the hydraulic model are presented in the Bridge Hydraulic Summary, Appendix B, and figure 7.

Channel roughness factors (Manning's " $n$ ") used in the hydraulic model were estimated using field inspections at each cross section following the general guidelines described by Arcement, Jr. and Schneider (1989). Final adjustments to the values were made during the modelling of the reach. Channel " $\mathrm{n}$ " values for the reach ranged from 0.040 to 0.050 , and overbank " $n$ " values were 0.025 for driveways and lawn areas.

Normal depth at the exit section (EXITX) was assumed as the starting water surface. This depth was computed by use of the slope-conveyance method outlined in the User's manual for WSPRO (Shearman, 1990). The slope used was $0.003 \mathrm{ft} / \mathrm{ft}$ which was estimated from the Flood Insurance Study for the town of Chelsea (FEMA, 1980).

The surveyed approach section (APPRO) was used, as surveyed, at one bridge length upstream of the upstream bridge face as recommended by Shearman and others (1986). This approach also provides a consistent method for determining scour variables.

The roadway section (RDWAY) was shortened to remove ineffective flow area caused by houses on all banks. The ends of the surveyed section were truncated at the surveyed ends of the exit (EXITX) section.

The incipient overtopping discharge was determined to be $2,080 \mathrm{ft}^{3} / \mathrm{s}$ 


\section{Bridge Hydraulics Summary}

\begin{tabular}{llll} 
Average bridge embankment elevation & 501.6 & $f t$ \\
\cline { 3 - 3 } Average low steel elevation & 498.2 & $\boldsymbol{f t}$
\end{tabular}

100-year discharge $\quad 5,350 \quad \mathrm{ft}^{3} / \mathrm{s}$

Water-surface elevation in bridge opening $\quad 498.3 \quad f t$

Road overtopping? ___ Y Discharge over road _ $\quad 2,530$, s

Area of flow in bridge opening $\quad 248 \quad \boldsymbol{f t}^{2}$

Average velocity in bridge opening $11.3 \mathrm{ft} / \mathrm{s}$

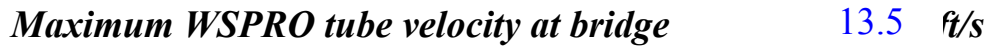

Water-surface elevation at Approach section with bridge $\quad 504.1$

Water-surface elevation at Approach section without bridge $\quad 501.3$

Amount of backwater caused by bridge $\quad 2.8$ it

500-year discharge $\quad 6,900 \quad \mathrm{ft}^{3} / \mathrm{s}$

Water-surface elevation in bridge opening $\quad 498.3$ ft

Road overtopping? ___ Y Discharge over road _ $\quad 3,870, \mathrm{~J} / \mathrm{s}$

Area of flow in bridge opening _ $\quad 248 \quad \mathrm{ft}^{2}$

Average velocity in bridge opening $11.7 \mathrm{ft} / \mathrm{s}$

Maximum WSPRO tube velocity at bridge 14.0 's

Water-surface elevation at Approach section with bridge 505.0

Water-surface elevation at Approach section without bridge $\quad 502.1$

Amount of backwater caused by bridge 2.9 .

Incipient overtopping discharge _ 2,080 $\mathrm{ft}^{3} / \mathrm{s}$

Water-surface elevation in bridge opening $498.3 \quad$ t

Area of flow in bridge opening $\quad 248 \quad \mathrm{ft}^{2}$

$\begin{array}{lll}\text { Average velocity in bridge opening } & 8.4 \quad \mathrm{ft} / \mathrm{s}\end{array}$

Maximum WSPRO tube velocity at bridge $\quad 10.0 \mathrm{ft} / \mathrm{s}$

Water-surface elevation at Approach section with bridge

Water-surface elevation at Approach section without bridge

Amount of backwater caused by bridge $\quad 1.4$ it

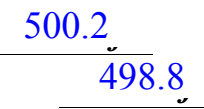




\section{Scour Analysis Summary}

\section{Special Conditions or Assumptions Made in Scour Analysis}

Scour depths were computed using the general guidelines described in Hydraulic Engineering Circular 18 (Richardson and others, 1993). Scour depths were calculated assuming an infinite depth of erosive material and a homogeneous particle-size distribution. The results of the scour analysis are presented in tables 1 and 2 and a graph of the scour depths is presented in figure 8 .

The 100-year, 500-year and incipient road over-flow discharges resulted in submerged orifice flow. Contraction scour at bridges with orifice flow is best estimated by use of the Chang pressure-flow scour equation (oral communication, J. Sterling Jones, October 4, 1996). Therefore, contraction scour for these three discharges was computed by use of the Chang equation (Richardson and others, 1995, p. 145-146). In this case, the 500year discharge model resulted in the worst case contraction scour with a scour depth of 5.1 $\mathrm{ft}$. The results of Laursen's clear-water contraction scour (Richardson and others, 1993, p. 35 , equation 18) for the three events were also computed and can be found in appendix F. For contraction scour computations, the average depth in the contracted section (AREA/ TOPWIDTH) is subtracted from the depth of flow computed by the scour equation (Y2) to determine the actual amount of scour.

Abutment scour for both abutments at all modelled discharges was computed by use of the Froehlich equation (Richardson and others, 1993, p. 49, equation 24). Parameters for the Froehlich equation include the Froude number of the flow approaching the embankments, the length of the embankment blocking flow, and the depth of flow approaching the embankment less any roadway overtopping. 


\section{Scour Results}

$$
\text { 100-yr discharge 500-yr discharge }
$$

Contraction scour:

Main channel

Live-bed scour

Clear-water scour

Depth to armoring

Left overbank

Right overbank

Local scour:

Abutment scour

Left abutment

Right abutment

Pier scour

Pier 1

Pier 2

Pier 3
(Scour depths in feet)
Incipient
rtopping
harge

(Scour depths infeet) 


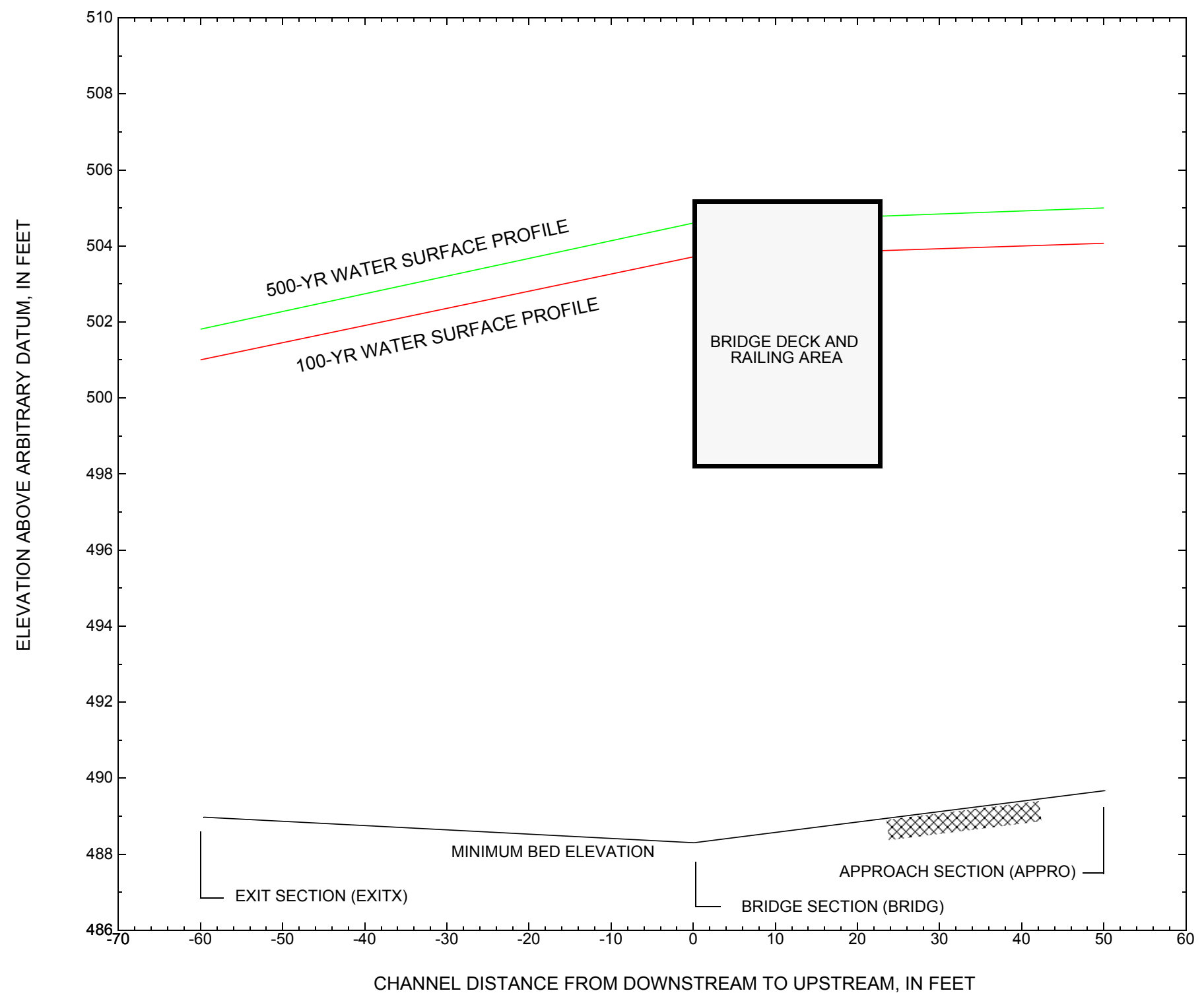

Figure 7. Water-surface profiles for the 100- and 500-yr discharges at structure CHELTH00440045 on town highway 44, crossing First Branch White River, Chelsea, Vermont. 


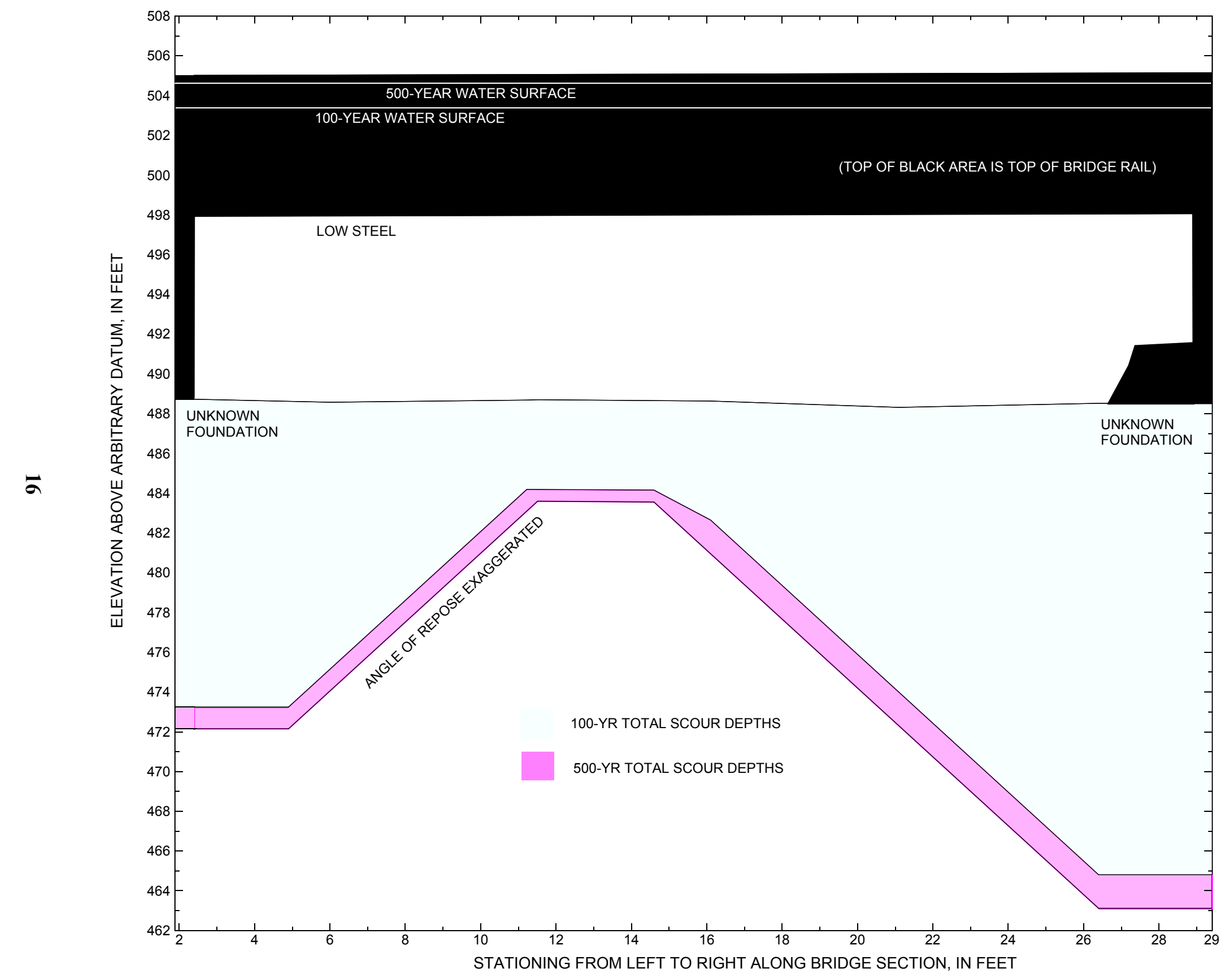

Figure 8. Scour elevations for the 100-yr and 500-yr discharges at structure CHELTH00440045 on town highway 44, crossing First Branch White River, Chelsea, Vermont. 
Table 1. Remaining footing/pile depth at abutments for the 100-year discharge at structure CHELTH00440045 on Town Highway 44, crossing First Branch White River, Chelsea, Vermont.

[VTAOT, Vermont Agency of Transportation; --,no data]

\begin{tabular}{|c|c|c|c|c|c|c|c|c|c|c|c|}
\hline Description & Station $^{1}$ & $\begin{array}{l}\text { VTAOT } \\
\text { minimum } \\
\text { low-chord } \\
\text { elevation } \\
\text { (feet) }\end{array}$ & $\begin{array}{l}\text { Surveyed } \\
\text { minimum } \\
\text { low-chord } \\
\text { elevation } \\
\text { (feet) }\end{array}$ & $\begin{array}{c}\text { Bottom of } \\
\text { footing } \\
\text { elevation } \\
\text { (feet) }\end{array}$ & $\begin{array}{l}\text { Channel } \\
\text { elevation at } \\
\text { abutment/ } \\
\text { pier }^{2} \\
\text { (feet) }\end{array}$ & $\begin{array}{l}\text { Contraction } \\
\text { scour depth } \\
\text { (feet) }\end{array}$ & $\begin{array}{l}\text { Abutment } \\
\text { scour } \\
\text { depth } \\
\text { (feet) }\end{array}$ & $\begin{array}{l}\text { Pier } \\
\text { scour } \\
\text { depth } \\
\text { (feet) }\end{array}$ & $\begin{array}{l}\text { Depth of } \\
\text { total scour } \\
\text { (feet) }\end{array}$ & $\begin{array}{c}\text { Elevation of } \\
\text { scour }^{2} \\
\text { (feet) }\end{array}$ & $\begin{array}{c}\text { Remaining } \\
\text { footing/pile } \\
\text { depth } \\
\text { (feet) }\end{array}$ \\
\hline \multicolumn{12}{|c|}{100 -yr. discharge is 5,350 cubic-feet per second } \\
\hline Left abutment & 2.4 & -- & 498.3 & -- & 488.8 & 4.5 & 11.0 & -- & 15.5 & 473.3 & -- \\
\hline Right abutment & 28.9 & -- & 498.2 & -- & 488.5 & 4.5 & 19.2 & -- & 23.7 & 464.8 & -- \\
\hline
\end{tabular}

1. Measured along the face of the most constricting side of the bridge.

2. Arbitrary datum for this study.

Table 2. Remaining footing/pile depth at abutments for the 500-year discharge at structure CHELTH00440045 on Town Highway 44, crossing First Branch White River, Chelsea, Vermont.

[VTAOT, Vermont Agency of Transportation; --, no data]

\begin{tabular}{|c|c|c|c|c|c|c|c|c|c|c|c|}
\hline Description & Station $^{1}$ & $\begin{array}{l}\text { VTAOT } \\
\text { minimum } \\
\text { low-chord } \\
\text { elevation } \\
\text { (feet) }\end{array}$ & $\begin{array}{l}\text { Surveyed } \\
\text { minimum } \\
\text { low-chord } \\
\text { elevation } \\
\text { (feet) }\end{array}$ & $\begin{array}{l}\text { Bottom of } \\
\text { footing } \\
\text { elevation } \\
\text { (feet) }\end{array}$ & $\begin{array}{c}\text { Channel } \\
\text { elevation at } \\
\text { abutment/ } \\
\text { pier }^{2} \\
\text { (feet) }\end{array}$ & $\begin{array}{l}\text { Contraction } \\
\text { scour depth } \\
\text { (feet) }\end{array}$ & $\begin{array}{c}\text { Abutment } \\
\text { scour } \\
\text { depth } \\
\text { (feet) }\end{array}$ & $\begin{array}{l}\text { Pier } \\
\text { scour } \\
\text { depth } \\
\text { (feet) }\end{array}$ & $\begin{array}{l}\text { Depth of } \\
\text { total scour } \\
\text { (feet) }\end{array}$ & $\begin{array}{c}\text { Elevation of } \\
\text { scour }^{2} \\
\text { (feet) }\end{array}$ & $\begin{array}{c}\text { Remaining } \\
\text { footing/pile } \\
\text { depth } \\
\text { (feet) }\end{array}$ \\
\hline \multicolumn{12}{|c|}{500 -yr. discharge is 6,900 cubic-feet per second } \\
\hline Left abutment & 2.4 & -- & 498.3 & -- & 488.8 & 5.1 & 11.5 & -- & 16.6 & 472.2 & -- \\
\hline Right abutment & 28.9 & -- & 498.2 & -- & 488.5 & 5.1 & 20.3 & -- & 25.4 & 463.1 & -- \\
\hline
\end{tabular}

1. Measured along the face of the most constricting side of the bridge.

2. Arbitrary datum for this study. 


\section{SELECTED REFERENCES}

Arcement, G.J., Jr., and Schneider, V.R., 1989, Guide for selecting Manning's roughness coefficients for natural channels and flood plains: U.S. Geological Survey Water-Supply Paper 2339, 38 p.

Barnes, H.H., Jr., 1967, Roughness characteristics of natural channels: U.S. Geological Survey Water-Supply Paper 1849,213 p.

Brown, S.A. and Clyde, E.S., 1989, Design of riprap revetment: Federal Highway Administration Hydraulic Engineering Circular No. 11, Publication FHWA-IP-89-016, 156 p.

Federal Highway Administration, 1983, Runoff estimates for small watersheds and development of sound design: Federal Highway Administration Report FHWA-RD-77-158

Federal Emergency Management Agency, 1980, Flood Insurance Study, Town of Chelsea, Orange County, Vermont: Washington, D.C., February 1980.

Froehlich, D.C., 1989, Local scour at bridge abutments in Ports, M.A., ed., Hydraulic Engineering--Proceedings of the 1989 National Conference on Hydraulic Engineering: New York, American Society of Civil Engineers, p. 13-18.

Hayes, D.C.,1993, Site selection and collection of bridge-scour data in Delaware, Maryland, and Virginia: U.S. Geological Survey WaterResources Investigation Report 93-4017, 23 p.

Interagency Advisory Committee on Water Data, 1982, Guidelines for determining flood flow frequency: U.S. Geological Survey, Bulletin 17B of the Hydrology Subcommittee, 190 p.

Johnson, C.G. and Tasker, G.D.,1974, Progress report on flood magnitude and frequency of Vermont streams: U.S. Geological Survey OpenFile Report 74-130, 37 p.

Lagasse, P.F., Schall, J.D., Johnson, F., Richardson, E.V., Richardson, J.R., Chang, F., 1991, Stream Stability at Highway Structures: Federal Highway Administration Hydraulic Engineering Circular No. 20, Publication FHWA-IP-90-014, 195 p.

Laursen, E.M., 1960, Scour at bridge crossings: Journal of the Hydraulics Division, American Society of Civil Engineers, v. 86, no. HY2, p. $39-53$.

Potter, W. D., 1957a, Peak rates of runoff in the Adirondack, White Mountains, and Maine woods area, Bureau of Public Roads

Potter, W. D., 1957b, Peak rates of runoff in the New England Hill and Lowland area, Bureau of Public Roads

Richardson, E.V. and Davis, S.R., 1995, Evaluating scour at bridges: Federal Highway Administration Hydraulic Engineering Circular No. 18, Publication FHWA-IP-90-017, 204 p.

Richardson, E.V., Harrison, L.J., Richardson, J.R., and Davis, S.R., 1993, Evaluating scour at bridges: Federal Highway Administration Hydraulic Engineering Circular No. 18, Publication FHWA-IP-90-017, 131 p.

Richardson, E.V., Simons, D.B., and Julien, P.Y., 1990, Highways in the river environment: Federal Highway Administration Publication FHWA-HI-90-016.

Ritter, D.F., 1984, Process Geomorphology: W.C. Brown Co., Debuque, Iowa, 603 p.

Shearman, J.O., 1990, User's manual for WSPRO--a computer model for water surface profile computations: Federal Highway Administration Publication FHWA-IP-89-027, 187 p.

Shearman, J.O., Kirby, W.H., Schneider, V.R., and Flippo, H.N., 1986, Bridge waterways analysis model; research report: Federal Highway Administration Publication FHWA-RD-86-108, 112 p.

Talbot, A.N., 1887, The determination of water-way for bridges and culverts.

U.S. Department of Transportation, 1993, Stream stability and scour at highway bridges, Participant Workbook: Federal Highway Administration Publication FHWA HI-91-011.

U.S. Geological Survey, 1981, Chelsea, Vermont 7.5 Minute Series quadrangle map: U.S. Geological Survey Topographic Maps, Scale $1: 24,000$. 


\section{APPENDIX A: \\ WSPRO INPUT FILE}




\section{WSPRO INPUT FILE}

GR

GR

GR

GR

$\mathrm{N}$

SA

\section{*}

$\mathrm{X}$

*

*

BR

*

GR

GR

GR

*

CD

$\mathrm{N}$

*

*

$\mathrm{XR}$

*

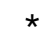

*

*

GR

GR

*

AS

GR

GR

GR

GR

*

$\mathrm{N}$

SA

HP 1 BRIDG

HP 2 BRIDG

HP 2 RDWAY

APPRO
U.S. Geological Survey WSPRO Input File chel045.wsp

Hydraulic analysis for structure CHELTH0440045 Date: 14-FEB-96

chelsea br 45 crossing first br white river, town highway 44 JDA

535069002080

$0.0030 \quad 0.0030 \quad 0.0030$

$62930 \quad 552553551516 \quad 17 \quad 13 \quad 3 * \begin{array}{llllllllll}15 & 14 & 23 & 21 & 11 & 12 & 4 & 7 & 3\end{array}$

$\operatorname{EXITX} \quad-60$

$\begin{array}{rrrrr}-62.0,501.32 & -10.9,498.22 & -2.6,493.87 & 0.0,490.58 \\ 3.7,489.73 & 7.7,488.96 & 13.3,489.35 & 21.9,489.79 \\ 30.4,490.45 & 30.6,490.63 & 37.4,494.41 & 43.9,496.66 \\ 118.7,498.95 & 119.0,508 & & & \end{array}$

$0.025 \quad 0.050 \quad 0.025$

FULLV $\quad 0 * * * 0.0030$

$\begin{array}{rcrr} & \text { SRD } & \text { LSEL } & \text { XSSKEW } \\ \text { BRIDG } & 0 & 498.2 & 5.0\end{array}$

$2.4,498.31$

$2.5,488.75$

$6.0,488.58$

$11.6,488.70$

$16.1,488.64$

$21.1,488.32$

$26.5,488.52$

$27.4,492.13$

$28.8,492.32$

$28.9,498.17$

$27.2,490.94$

$2.4,498.31$

BRTYPE BRWDTH EMBSS EMBELV WWANGL

$\begin{array}{lllll}4 & 24.4 & 2.7 & 500.7 & 67.8\end{array}$

0.040

SRD EMBWID IPAVE

$\begin{array}{llll}\text { RDWAY } & 12 & 22.4 & 1\end{array}$

Roadway included concrete bridge rails (-3.0,501.56, -3.0,505.01 and $31.6,505.21 \quad 31.6,501.56)$

$-62.0,502.00$

$31.6,505.21$

$-47.2,501.60$

$31.6,501.56$

$-3.0,501.56$

$113.2,500.13$

$-3.0,505.01$

$114.0,508$

$$
\begin{array}{rr}
50 & \\
-29.5, & 503.28 \\
3.7, & 490.01 \\
29.9, & 489.71 \\
79.8, & 498.29
\end{array}
$$$$
-12.1,497.69
$$$$
-3.3,494.42
$$$$
0.0,490.67
$$$$
11.2,490.07
$$$$
14.2,489.67
$$$$
25.8,489.76
$$$$
31.3,490.78
$$$$
39.4,495.67
$$$$
109.2,499.12
$$$$
109.2,508
$$

0.050

0.025

$$
39.4
$$

498.311498 .31

$498.31 * * 2803$

$503.71 * \star 2528$ 
WSPRO INPUT FILE (continued)

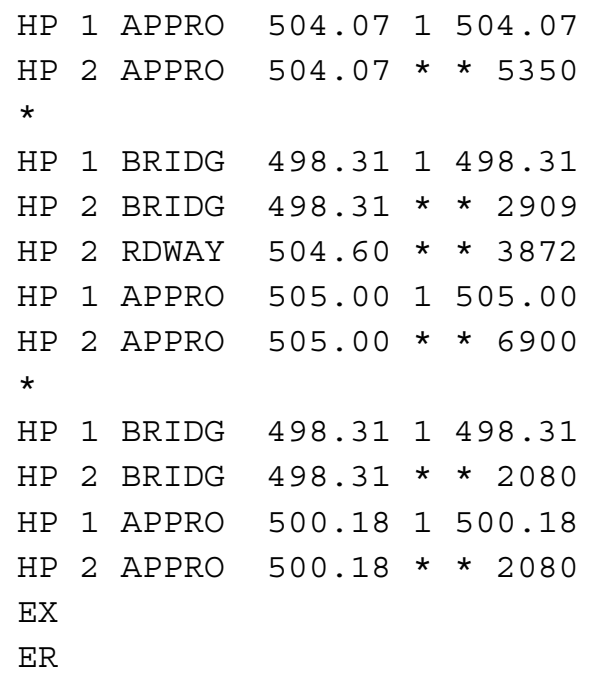




\section{APPENDIX B: \\ WSPRO OUTPUT FILE}




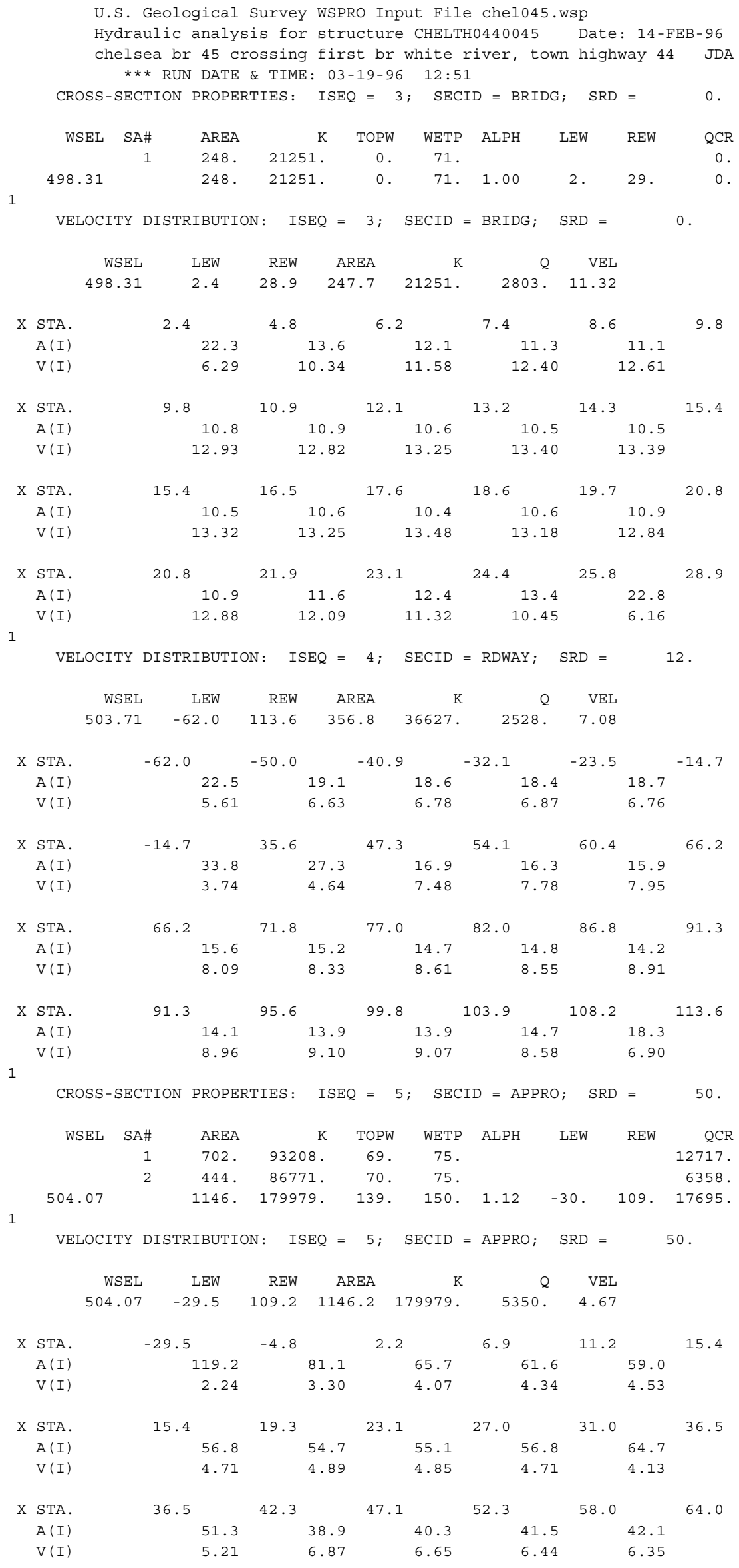




\section{WSPRO OUTPUT FILE (continued)}

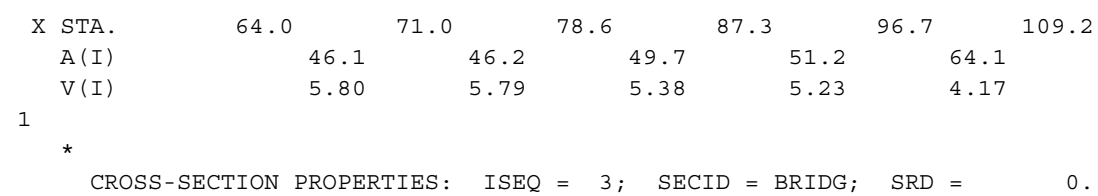




\section{WSPRO OUTPUT FILE (continued)}

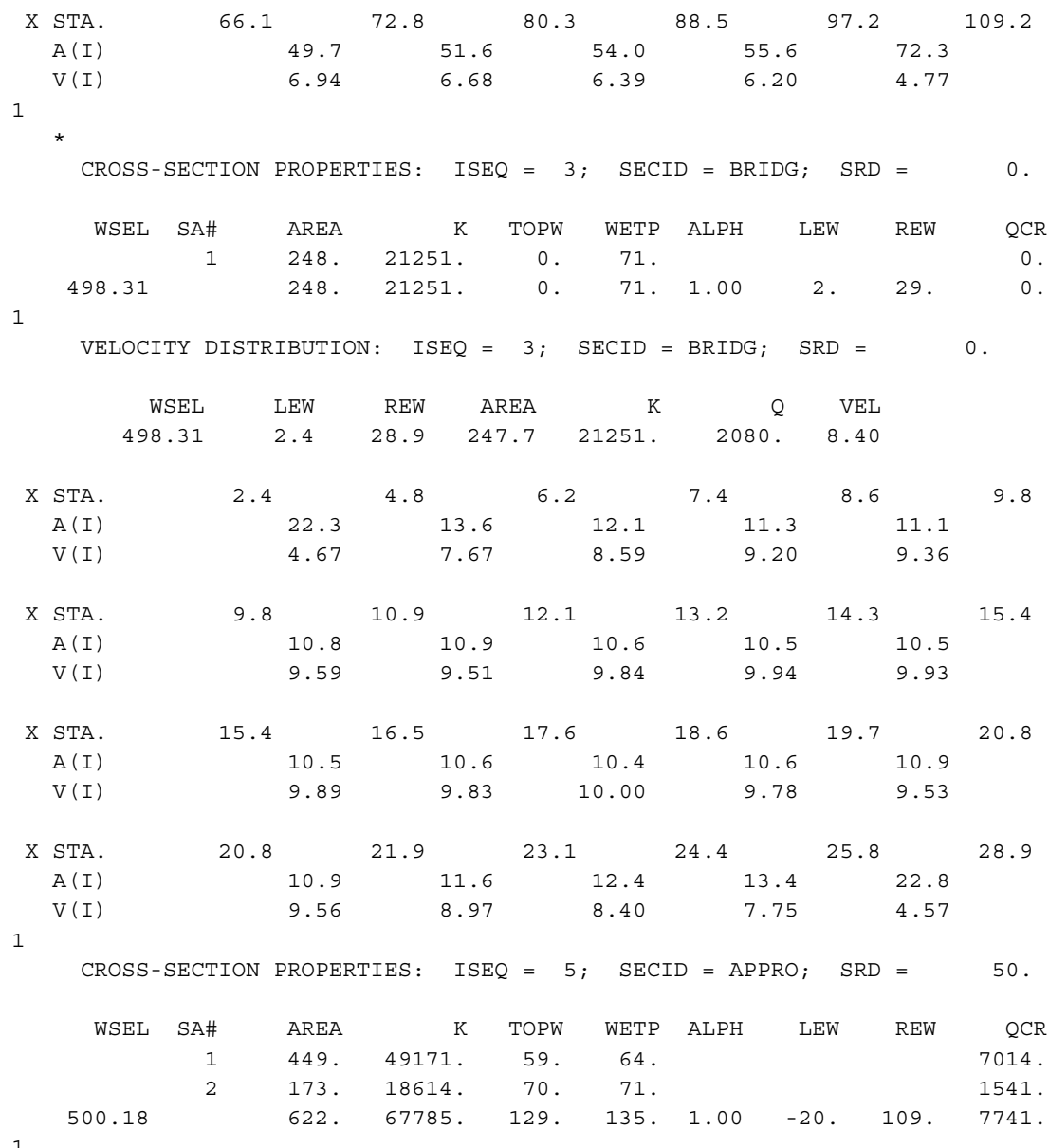

VELOCITY DISTRIBUTION : ISEQ $=5 ; \quad \operatorname{SECID}=$ APPRO; $\quad \operatorname{SRD}=50$.

$\begin{array}{rrrrrrr}\text { WSEL } & \text { LEW } & \text { REW } & \text { AREA } & \text { K } & Q & \text { VEL } \\ 500.18 & -19.9 & 109.2 & 621.6 & 67785 . & 2080 . & 3.35\end{array}$

\begin{tabular}{|c|c|c|c|c|c|c|c|c|c|c|c|}
\hline \multirow[t]{3}{*}{$\mathrm{x}$} & STA. & -19.9 & & -1.3 & & 2.7 & & 5.9 & & 8.8 & 11.5 \\
\hline & $A(I)$ & & 59.4 & & 38.2 & & 32.0 & & 29.5 & \multicolumn{2}{|c|}{27.7} \\
\hline & $V(I)$ & & 1.75 & & 2.72 & & 3.25 & & 3.53 & \multicolumn{2}{|c|}{3.76} \\
\hline \multirow[t]{3}{*}{$\mathrm{x}$} & STA. & 11.5 & & 14.1 & & 16.7 & & 19.1 & & \multirow[t]{3}{*}{21.6} & \multirow[t]{3}{*}{24.0} \\
\hline & $A(I)$ & & 27.2 & & 26.7 & & 25.8 & & 25.4 & & \\
\hline & $V(I)$ & & 3.82 & & 3.90 & & 4.04 & & 4.09 & & \\
\hline \multirow[t]{3}{*}{$\mathrm{x}$} & STA. & 24.0 & & 26.4 & & 28.9 & & 31.7 & & \multirow[t]{3}{*}{35.7} & \multirow[t]{3}{*}{42.} \\
\hline & $A(I)$ & & 25.3 & & 25.3 & & 28.2 & & 32.0 & & \\
\hline & $V(I)$ & & 4.12 & & 4.11 & & 3.68 & & 3.25 & & \\
\hline \multirow[t]{3}{*}{$\mathrm{X}$} & STA. & 42.0 & & 48.0 & & 55.0 & & 64.5 & & 78.6 & \multirow[t]{3}{*}{109.2} \\
\hline & $A(I)$ & & 24.9 & & 26.2 & & 30.3 & & 34.1 & & \\
\hline & $V(I)$ & & 4.18 & & 3.97 & & 3.43 & & 3.05 & & \\
\hline
\end{tabular}

EX

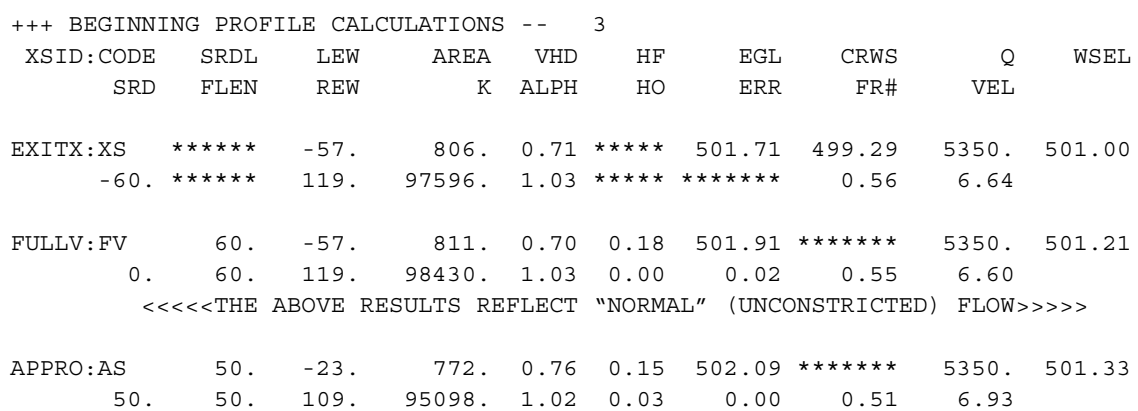




\title{
WSPRO OUTPUT FILE (continued)
}

\author{
$\ll<<$ THE ABOVE RESULTS REFLECT "NORMAL" (UNCONSTRICTED) FLOW >>>>>
}

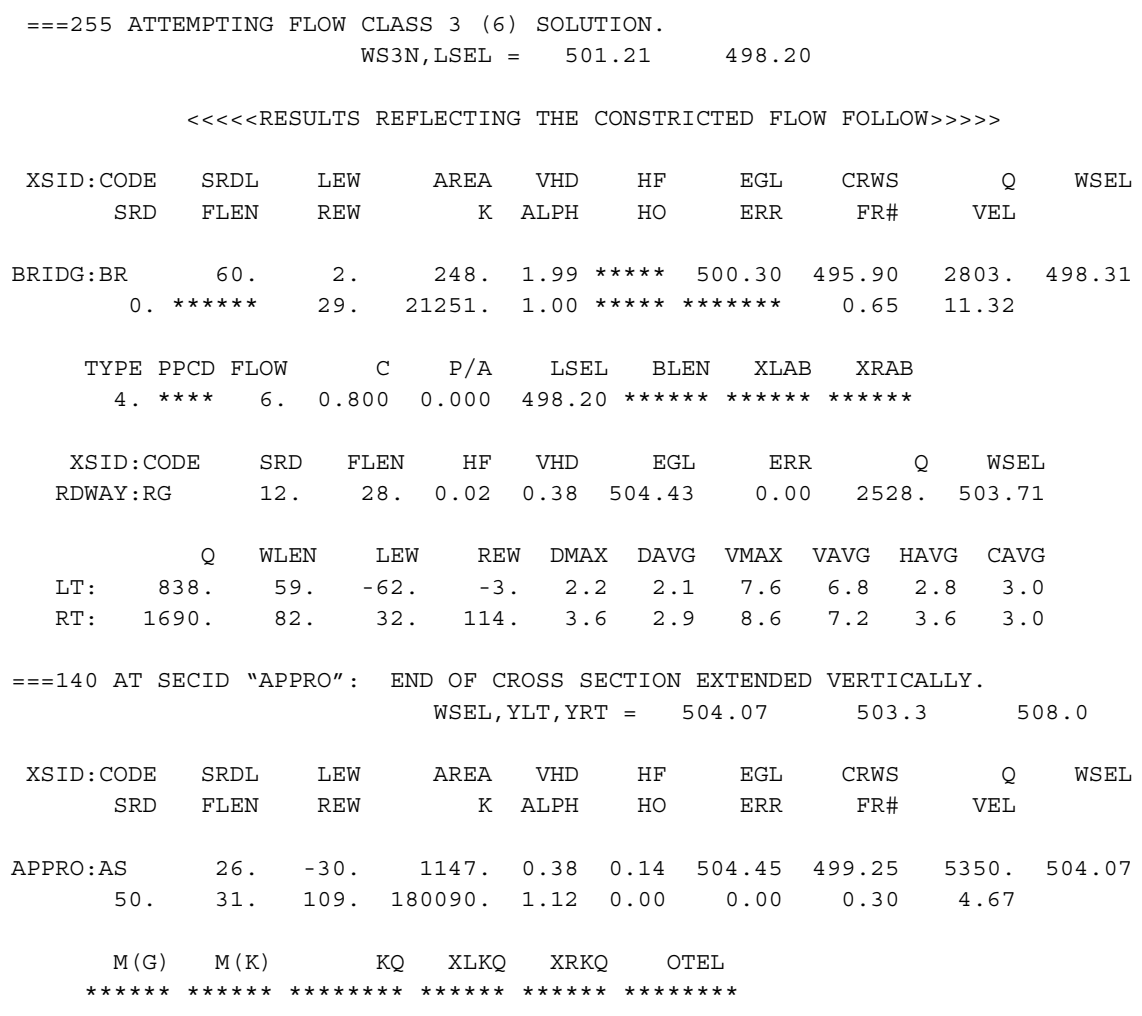


WSPRO OUTPUT FILE (continued)

\begin{tabular}{|c|c|c|c|c|c|c|c|c|c|c|c|}
\hline \multirow{2}{*}{$\begin{array}{r}\text { XSID : CODE } \\
\text { SRD }\end{array}$} & \multicolumn{2}{|c|}{ SRDL } & LEW & AREA & VHD & $\mathrm{HF}$ & EGL & \multicolumn{2}{|c|}{ CRWS } & Q & \multirow[t]{2}{*}{ WSEL } \\
\hline & & LEN & REW & K & ALPH & $\mathrm{HO}$ & ERR & $\mathrm{FF}$ & & VEL & \\
\hline \multirow{2}{*}{$\begin{array}{r}\text { BRIDG : BR } \\
0 .\end{array}$} & \multicolumn{2}{|c|}{60.} & 2. & 248 . & $2.14 *$ & $\star * \star * \star$ & 500.45 & 496. & \multicolumn{2}{|r|}{2909.} & \multirow[t]{2}{*}{498.31} \\
\hline & . $* \star \star *$ & $\star * *$ & 29. & 21251. & $1.00 *$ & $\star \star \star \star * \quad \star * *$ & $* * \star \star * *$ & 0.6 & & 11.74 & \\
\hline TYPE & PPCD & FLOW & C & $\mathrm{P} / \mathrm{A}$ & LSEL & BLEN & XLAB & & & & \\
\hline 4. & $\star \star \star \star *$ & 6. & 0.800 & 0.000 & 498.20 & 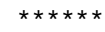 & 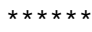 & $\star \star \star \star \star * *$ & & & \\
\hline XSID:C & CODE & SRD & FLEN & $\mathrm{HF}$ & VHD & EGL & ERR & & $Q$ & WSEI & \\
\hline RDWAY : R & & 12. & 28. & 0.03 & 0.52 & 505.49 & -0.02 & & 72 . & 504.60 & \\
\hline & $Q$ & WLEN & LEW & REW & DMAX & DAVG & VMAX & VAVG & HAVG & CAVG & \\
\hline LT: & 1361. & 59. & -62 . & -3 . & 3.0 & 3.0 & 9.0 & 7.8 & 3.9 & 3.1 & \\
\hline $\mathrm{RT}:$ & 2511. & 82 . & 32. & 114. & 4.5 & 3.7 & 9.9 & 8.2 & 4.6 & 3.1 & \\
\hline
\end{tabular}

$==140 \mathrm{AT}$ SECID "APPRO": END OF CROSS SECTION EXTENDED VERTICALLY.

\begin{tabular}{|c|c|c|c|c|c|c|c|c|c|c|}
\hline \multirow[b]{2}{*}{ XSID : CODE } & \multirow[b]{2}{*}{ SRDL } & \multirow[b]{2}{*}{ LEW } & \multicolumn{3}{|c|}{ WSEL, YLT, YRT } & $=$ & 505.00 & 503.3 & \multicolumn{2}{|c|}{508.0} \\
\hline & & & & AREA & VHD & $\mathrm{HF}$ & EGL & CRWS & Q & WSEL \\
\hline SRD & FLEN & REW & & K & $\mathrm{ALPH}$ & $\mathrm{HO}$ & ERR & FR\# & VEL & \\
\hline APPRO : AS & 26. & -30 & & 1275 . & 0.52 & 0.17 & 505.52 & 499.90 & 6900 & 505.00 \\
\hline 50. & 32. & 109. & & 14922 . & 1.14 & 0.00 & -0.02 & 0.34 & 5.41 & \\
\hline$M(G)$ & $\mathrm{M}(\mathrm{K})$ & & KQ & XLKQ & $\mathrm{XRKS}$ & & TEL & & & \\
\hline$\star \star \star \star \star \star \star *$ & $\star \star \star \star \star \star \star *$ & $\star \star \star \star \star *$ & $\star \star \star *$ & 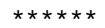 & $\star \star \star \star \star \star *$ & * * & $* * *$ & & & \\
\hline
\end{tabular}

$<<<<$ END OF BRIDGE COMPUTATIONS $>>>>>$

FIRST USER DEFINED TABLE.

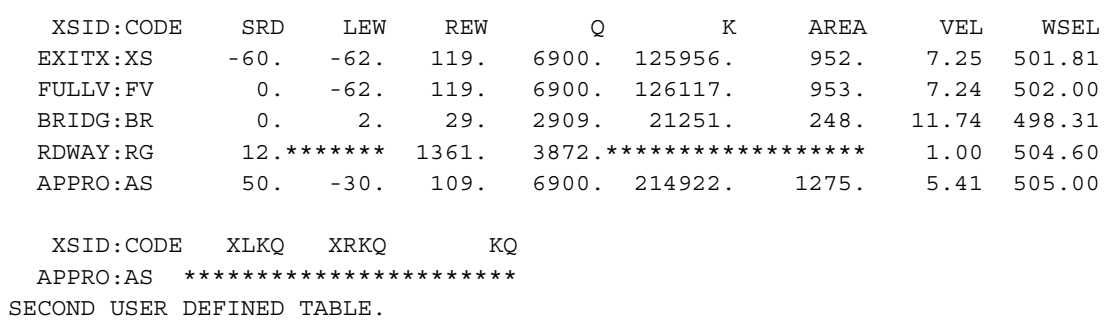

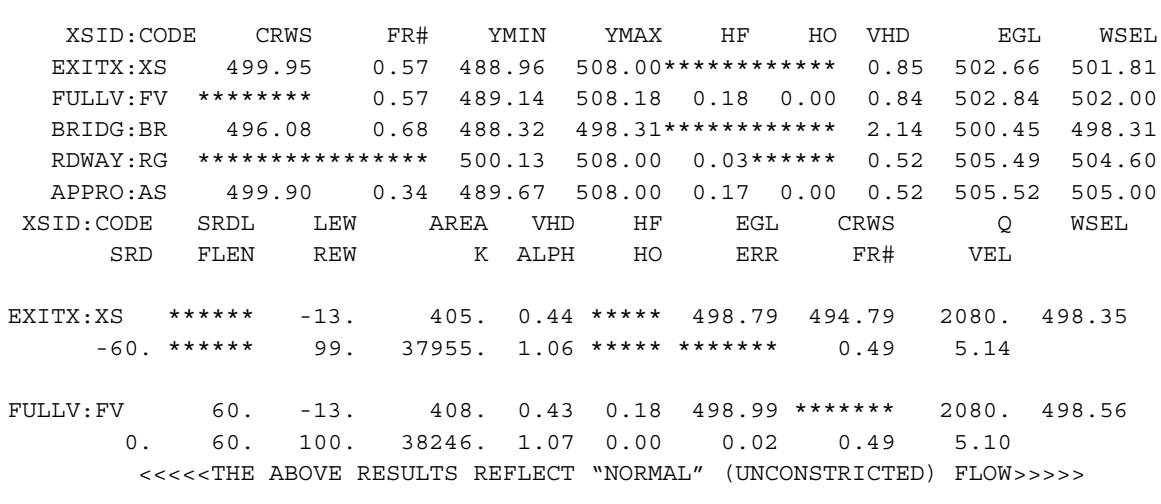


WSPRO OUTPUT FILE (continued)

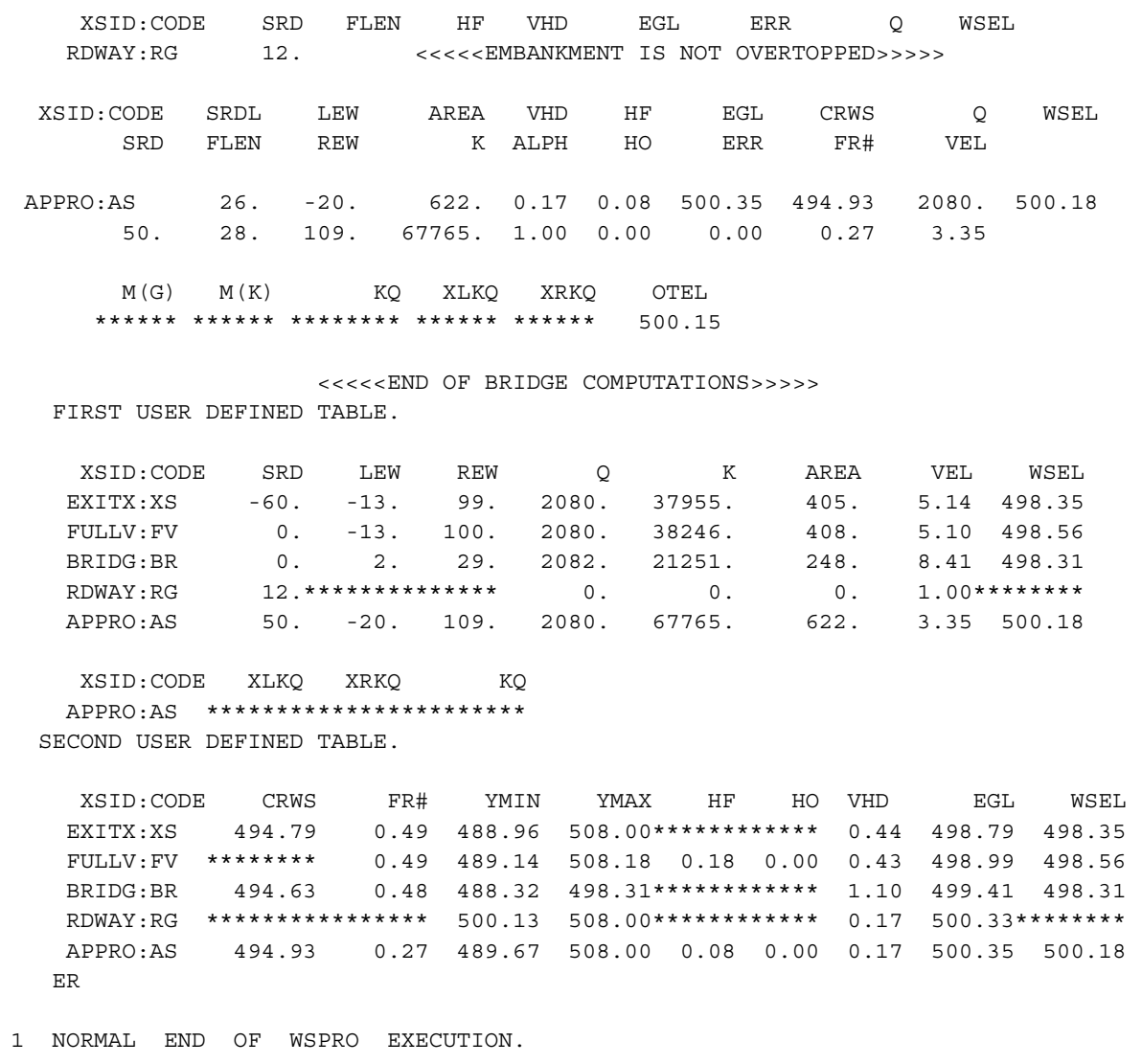




\section{APPENDIX C:}

\section{BED-MATERIAL PARTICAL-SIZE DISTRIBUTION}




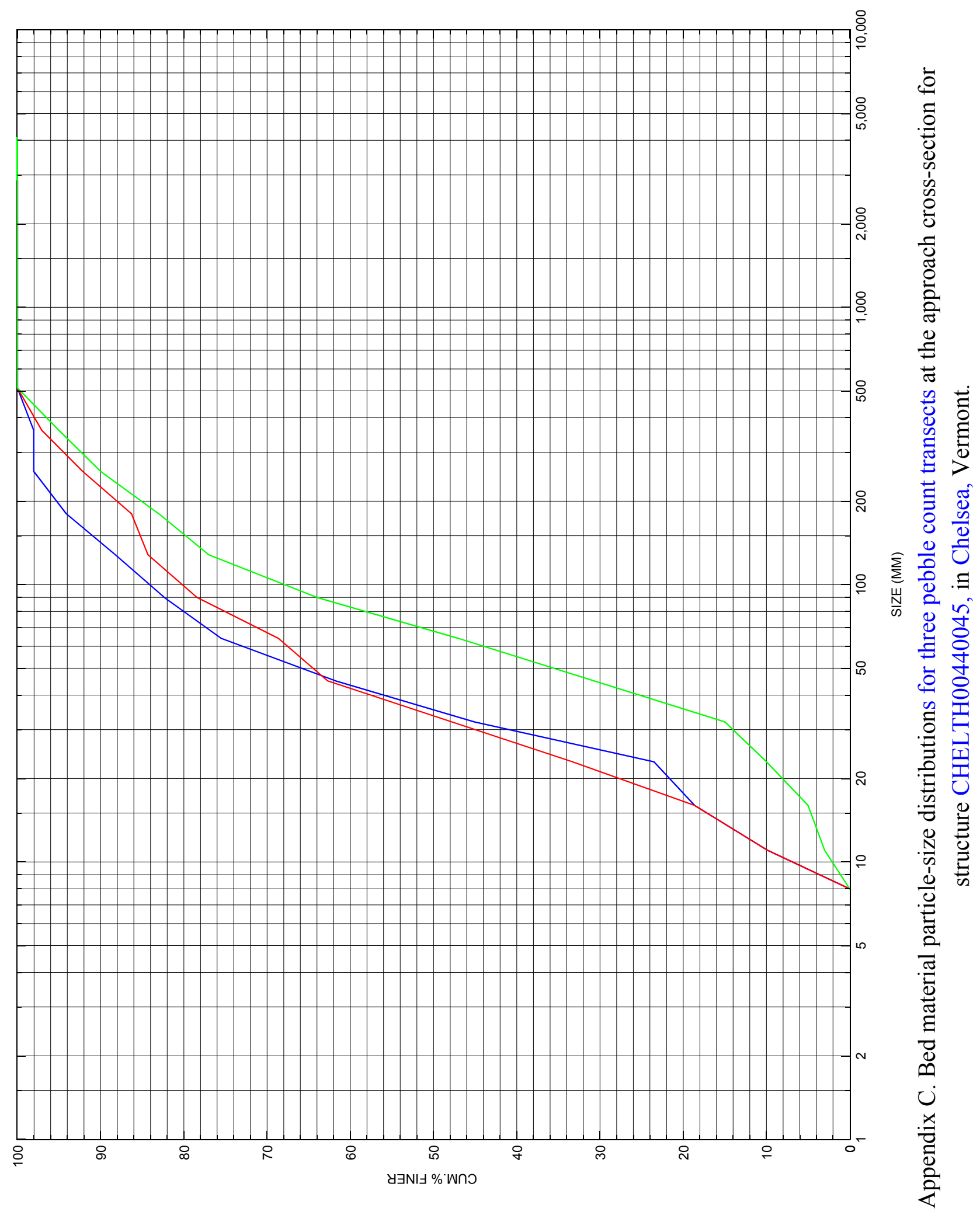




\section{APPENDIX D: \\ HISTORICAL DATA FORM}

